\title{
The effect of Beetle leaves (Piper betle linn) for dental caries formation
}

\author{
Adi Kurniawan, Milly Armilya A., Ayu Trisna Hayati \\ Department of Conservative Dentistry Faculty of Dentistry Universitas Padjadjaran
}

\begin{abstract}
Dental caries is still the main problem in dental and oral health. Caries is caused by several factors working simultaneously. The main principle of management caries is by prioritizing preventive action and avoiding invasive action. Beetle leaves are medicamentous plant which are widely cultivated and very beneficial for Indonesian people. Its active content enable beetle leaves to be used as antimicrobial, antiseptic, antifungal, antioxidant, and disinfectant. The government of Indonesia and WHO greatly support the utilization of natural resources as medical cure. Currently we can find a lot of toothpaste and mouthwash products which use beetle leaves as additional ingredient. Various researches have proved that the use of beetle leaves extract as mouthwash, toothpaste and chewing beetle leaves may decrease plaque score. Chavicol and chavibetol content enable beetle leaves to function as very good antimicrobial. Beetle leaves also contain charvacrol, eugenol, methyl eugenol, cadinene, and seskuiterpene, which can function as antiseptic. Beetle leaves may effect salivary function and secretion and also impede the forming of dental caries.
\end{abstract}

Key words: Caries, beetle leaves, antimicrobial, saliva.

\section{INTRODUCTION}

Indonesia as one of tropical countries has a very rich flora. One of the floras is various plants potential for medical world as herbal medicine and antimicrobials. For an example, betel (Piper Betel Linn) known as herbal medicine contains antimicrobial agents.

The betel empirically regards as restorative plant which can cure various diseases. Some experimental research proved that all parts of the betel can be use as medicine; however the most potential part are its leaves, which have stimulants, prophylactic, tonic and astringent effect. ${ }^{1}$ According to Prayogo et $\mathrm{al}^{2}$, the essential oil of
Betel leaves can be used for the basic ingredients of drug because it contains phenol compound component which is as powerful as antiseptic.

Dental caries is the process of damaging and softening enamel and dentin. Dental caries are diseases begin with progressive damage in the hard outer part of teeth i.e. enamel, dentin, and cementum. It caused by metabolism activity of bacteria in the plaque caused the demineralization of the hard outer part of teeth. ${ }^{2,3}$

Dental caries and periodontal diseases became the major problem in today medical worlds especially in oral and dental health. Plaque is a bio-film consists of large quantity of various bacteria that form on teeth. Bacteria can 
form colonies stuck on teeth and produce acid as metabolism product. These can faster the built of plaque which can cause the decrease of $\mathrm{pH}$ level on teeth. If the $\mathrm{pH}$ reaches the critical level (5.25.5), then the enamel will be dissolved and caused the dental caries. ${ }^{3}$

There are various ways to prevent the formation of bacterial colonist in oral cavity. One of them is used as antibiotic. The antibiotic formerly used to cure infection; however, nowadays it is found out that it can also cause the build of new resistance mutants. Dental caries prevention can be done by brushing teeth and washing the mouth. At present, various toothpastes and mouthwash are improved. Based on some experiments, certain toothpastes and mouthwash ingredients have some side-effects. However, the used still can not reach all community. ${ }^{4}$

Indonesian government and World Health Organization has made a policy in using natural resource as medicine, in order to distribute health service for all segments of communities evenly. That's the reason why at present, many improvements on toothpaste and mouthwash is using betel leaves as the basic source and known as herbal toothpaste or mouthwash.

Betel leaves which is familiar for Indonesian often used for betel chewing and also one of natural source for gargle and prevent dental and oral infection. ${ }^{5}$ Betel leaves is an antiseptic to kill micro-organism like caries bacteria in the oral. According to some scientists, betel leaves contained active anti-microbial oil to obstruct or slow microbial growth. ${ }^{5,6}$

Betel leaves are useful plants for Indonesian. Beside that, the active ingredients contained in betel leaves make it valuable as antiseptic or antimicrobial. Based on those principles, the writer interested to write a topic on the influence of betel leaves in dental caries formation.

\section{CARIES AND BETEL LEAVES}

Carious lesion can only happen if there are bacteria which can produce acid and turn the teeth environment into acidic; furthermore it can cause dental demineralization. Caries can be classified based on the anatomy area in which the caries happened. The variations of carious lesion depends on the surface of the teeth in which the lesion existed and the development of the lesion itself. ${ }^{7}$

\section{Risk factor}

The prevalence and incidence of caries can be decreased by a good self-care and dentist/ medical care. The success of dental health protection depends on our self-care process, such as, plaque control program, using fluoride tooth paste, and doing scaling, root planning, or varnishing with fluoride periodically. To protect our dental health; beside above internal care we also need to give attention to external care, for example the frequency of the habits of carbohydrate consumption. ${ }^{8}$

Caries risk factors varied in ages, individual health teeth and teeth surface, so that to decide what the best protection for carious lesion is, we need to know the variation of those caries risk prediction. Some former experiments found out that the frequency of caries risk different through ages. For example, in children, caries usually occurs in eruption period of permanent molar and the secondary maturation enamel period.

Each individual has varied caries risk. Individual risk factors are the fusion of varied factors and classified into no risk, low risk, risky, and high risk. These criterions are different based on various caries possibility in different ages and to understand other caused. However, by this way, the result hopefully more accurate for the individual caries risk. ${ }^{8}$

Besides the individual variation, caries risk also influenced by teeth. According to Axelsson et al. ${ }^{8}$ at the age of 50 , the most remain teeth is mandibular incisor. That's why posterior teeth need more complex protection, for example, pit and fissure fillings, flour application and approximate areas cleaning.

The surface of teeth can caused variation of risk. It proves by caries risk is higher on pit and fissure areas i.e. $M$ and $P$ teeth, rather than enamel surface. The difference of caries risk on every teeth surface influenced the preventive, diagnose and caries handling, with considering the condition of teeth surface. At posterior teeth proximate areas restoration, the cleanest of the restoration need more attention, because this area is easier to get secondary caries, than the 
restoration in back teeth areas. ${ }^{8}$

\section{Chemistry composition of betel leaves}

Betel leaves contains betel oil, terpenes, sesquiterpenes, phenyl-propane, tannin, diastase, carotene, thyamine, riboflavin, nicotine acid, vitamin C, sugar, starch, and amino acid. ${ }^{9}$ Fresh young betel leaves has more diastase, sugar, and betel oil than old betel leaves, but the amount

Table 1. Chemical composition of $100 \mathrm{~g}$ fresh betel leaves. ${ }^{11}$

\begin{tabular}{lc}
\hline \multicolumn{1}{c}{ Component } & Total \\
\hline Water & $85.4 \mathrm{mg}$ \\
Protein & $3.1 \mathrm{mg}$ \\
Fat & $0.8 \mathrm{mg}$ \\
Carbohydrate & $6.1 \mathrm{mg}$ \\
Fiber & $2.3 \mathrm{mg}$ \\
Minerals & $2.3 \mathrm{mg}$ \\
Calcium & $230 \mathrm{mg}$ \\
Phosphoric & $40 \mathrm{mg}$ \\
Iron & $7 \mathrm{mg}$ \\
lon-iron & $3.5 \mathrm{mg}$ \\
Carotene & $9600 \mathrm{IU}$ \\
Thyamine & $70 \mu \mathrm{g}$ \\
Ribovlafin & $30 \mu \mathrm{g}$ \\
Nicotine acid & $0.7 \mathrm{mg}$ \\
Vitamin C & $5 \mathrm{mg}$ \\
lodine & $3.4 \mu \mathrm{g}$ \\
Pottasium nitrate & $0.26-0.42 \mathrm{mg}$ \\
\hline
\end{tabular}

Table 2. Chemical composition in betel oil of betel leaves. ${ }^{11}$

\begin{tabular}{lc}
\hline \multicolumn{1}{c}{ Chemical components } & Composition (\%) \\
\hline Phenol compound & \\
Chavicol & 5.40 \\
Charvacrol & 4.40 \\
Chavibetol & 40.50 \\
Eugenol methyl ether & 3.50 \\
Cineole & - \\
Estragol & 6.50 \\
Allypyrocathecol & 7.50 \\
Non phenol compound & \\
Terpene & 2.30 \\
Caryophyllene & 11.90 \\
Cardinene & 9.10 \\
Seskuiterpen & 7.50 \\
P-cymene & - \\
Polymerized oil & 0.90 \\
\hline
\end{tabular}

of tannin is relatively the same. ${ }^{10}$ Chemical composition of betel leaves can be seen on Table 1 .

Beside that, betel leaves extract also contains malt-acid, oxalate-acid and nicotineacid. A few amino acid also found in betel leaves i.e. asparagine, prolyne, onitrin, tyrosine, methyonine, valine, aspartat acid, glutamate acid, phenylalanin and leusin, meanwhile the kinds of amino acid that uncontained in betel leaves are lysine, histidine and arganine. ${ }^{12}$

Betel leaves contained about $0.9-1.87 \%$ of betel oil. The active ingredients of betle oil are chavicol, chavibetol (betlephenol), allypyrocathecol-mono dan allypyrocathecol-diacetate, charvacrol, eugenol, eugenol methylether, p-cymene, cineole, caryophylene, cardinene, dan estragol. ${ }^{9}$

\section{Anti-bacterial activity in betel leaves}

The result of antibacterial experiment by the diffusion well, which divided into four kinds of betel leaves, i.e. black, green, yellow and red betel leaves, showed that black betel leaves have the strongest anti-bacterial activity. ${ }^{13}$ According to Sukarminah ${ }^{13}$, black betel leaves showed the defense against Staphylococcus aureus about 6 $\mathrm{mm}$ and $3 \mathrm{~mm}$ against Pseudomonas aeruginosa bacteria. Green betel leaves defense occurred against Staphylococcus aureus and Pseudomonas aeruginosa bacteria at about $4 \mathrm{~mm}$ and $1 \mathrm{~mm}$. Yellow and red betel leaves has defensive activities against the growth of Staphylococcus aureus bacteria each at $3 \mathrm{~mm}$, but the obstruct against Pseudomonas aeruginosa was not showed.

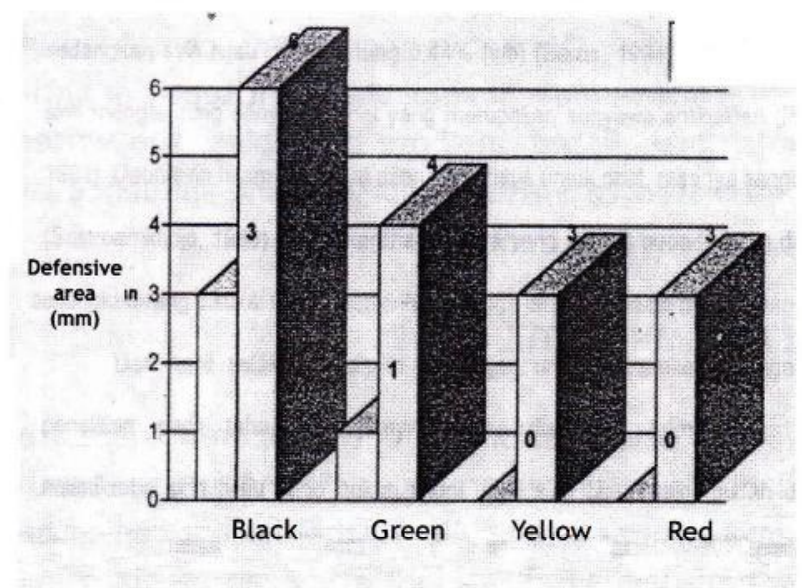

Figure 1. Antibacterial activity of some kinds of betel leaves extract. ${ }^{13}$ 
The high level of betel leaves defensive activities believed as the result of the quantity of betel oil amount of black betel leaves at about $0.5 \%(\mathrm{v} / \mathrm{b})$, meanwhile green betel leaves has $0.44 \%(\mathrm{v} / \mathrm{b}) .{ }^{13}$

\section{DISCUSSION}

Caries is multifactor diseases, that is diseases caused by interaction between host teeth and saliva), particularly Streptococcus mutants and time-factor on which the food contact teeth. Thus, the interaction factors need to be obstructed to protect the teeth health and longevities. The preventive model has got high priority in Indonesian National Health System, including caries prevention. Caries-preventive method which is cheap, effective and reachable for Indonesian people is needed by development countries like Indonesia. ${ }^{3}$

The influences of betel leaves extract to anti microbial compound

Antimicrobial compound is chemical or biological compound which can prevent the growth and activities of microbe. Natural anti microbial compound mostly contained in spices. Spices has usually used to flavors foods, but some of the spices also have anti-oxidant and antimicro bacterial agents which is bacteriostatic and bacterisidal. ${ }^{11}$

Betel leaves proved to contain various natural anti microbe. ${ }^{11}$ The betel pharmacodinamic effect as anti-microbial agents produced by active phenol substance of betel leaves i.e. chavicol and chavibetol which has good bacteriostatic and bacterial acid. ${ }^{14}$ Phenol substance mechanism as anti microbe can be happened by destroying and breaking bacterial cell, then let the microbial cell protein settle, thus it will be poisonous for protoplasm. Phenolic compound which has bigger molecular weight can make the essential enzyme in the cell inactive, even with low concentrate. Furthermore, phenol compound can break the membrane and barrier permeability physically. ${ }^{13}$

Based on Anggriadi's ${ }^{15}$ research, gargling with boiling betel leaves can obstruct and kill Streptococuss $B$ bacteria better then chlorhexidine mouthwash. The in vitro experiment found that betel leaves can obstruct the growth of Streptococcus sanguis. Yunilawati ${ }^{16}$ also found that de- fensive area formed by betel oil against Streptococcus mutants bigger than defensive area formed by $\mathrm{NaF}$ against Streptococcus mutants at the concentrate of $0.1,0.25,0.5,0.75$ and $1 \%(b / v)$.

In dentistry phenol and its derivative frequently is used to stop the growth of some negative bacteria in oral cavity and Streptococcus mutants and also to decrease the amount of plaque. Betel consists of natural phenol which has the same function with synthesis phenol, even better. For those reason betel begin to be used for the mixed ingredients of mouthwash and toothpaste. .,17 $^{-17}$

The influence of boiled betel leaves as a mouthwash toward plaque.

Dental and oral health generally cannot be separated from food remains, plaque, and tartar in the mouth. Various ways have been done to prevent or stop the plaque from mechanically or chemically. The usage of mouthwash prevents bacterial sticking to the teeth in order to prevent the formed of plaque. Many kinds of industrial mouthwash products have been made and used by people, but the researchers found of that there are some side effect to the oral cavity. One of alternative medicines which is frequently used for preventing and curing the disease in the form of mouthwash is betel leaves. ${ }^{4}$

Antiseptic is a compound to stop the growth and development of bacteria. Washing mouth by antiseptic can reduce $94.1 \%$ bacteria compare than the control group. Gargled effect can reduce plaque in all research subjects. Furthermore, Goldman stated that gargle in another great effort in the oral-physiotherapy, because it cleans the remains of food from oral cavity. $17 \%$ amount of bacteria decrease in oral cavity after gargling with distilled water. The using of chemical compound in the form of mouthwash is needed in order to increase gargle effectivity to stop bacteria growth. ${ }^{4}$

Betel leaves pharmacodinamic effect as anti-septic occurs because of betel leaves active substance, such as charvacrol, eugenol, methyl eugenol, cardinene and sesquiterpene..$^{4,14}$ Kumala and Sudjono ${ }^{4}$ at 2006 have done a research with 40 samples which divided into 2 groups. The first group gargled with boiled betel leaves for four days and another group gargled with water for our 
days.

In Kumala and Sudjono ${ }^{4}$ research, both groups got scaling and root planning. The result of the plaque score counted in the pre-research are $\mathbf{2 . 5 7 4}$ for experimental group and 2.583 for control group. After four days the plaque score for experimental group is $\mathbf{1 . 9 3 3}$ and control group is 2.266 . This result showed us that there was no significant differences in the former plaque score, means that there was the same condition of the sample in the beginning of the research. After the fourth day, between the control group and experimental group there was significance differences of score decreased. Based on the result, the experimental groups has more decreasing plaque than the control group. ${ }^{4}$

\section{The influence of betel toothpaste on plaque}

Caries prevention can be done by brushing the teeth, which aims to reduce and prevent plaque accumulation. Splashing water, air or washing mouth can not dismiss the plaque perfectly, because plaque slicked to the surface, restoration, and tartar of the teeth. Although mechanically, clean the tooth using tooth brush is enough, the use of tooth paste with various ingredients, will help to take care of clean and health. Lastly, there are tooth paste contain betel leaves extract, that is the traditional ingredients which frequently used by community. ${ }^{17}$

According to Prahasanti ${ }^{17}$, there were the differences on accumulation of plaque between the usage of toothpaste with betel leaves extract and without betel leaves extract. The research showed that the accumulation score of plaque after using toothpaste with betel leaves extract after one hour, two hours and three hours approximately are 5.880, 1.300 and 0.004 . Meanwhile, the approximate scores after using toothpaste without betel leaves are 11.66, 13.54 and 14.00. It means that toothpaste with betel leaves extract is better in obstruct the growth of plaque than toothpaste without betel leaves extract.

Pharmacodinamic effect on betel leaves as antimicrobial, antiseptic, antioxidant, disinfectant and anti-fungal in oral activity caused the decrease of plaque amount. This pharmacodinamic characteristics produce by active substances contained on betel oil, such as chavicol, which has special smell and has bactericide characteristics with the five times bigger power than others phenol like chavibetol, charvacrol, eugenol, methyl-eugenol, terpenes, kardinen and sesquiterpenes. ${ }^{4,14}$ Moreover, the result of the experiment showed that betel leaves is one of plant with the highest antimicrobial activity against Streptococcus viridans and Streptococcus aureus bacterias. ${ }^{4}$ The obstruction of growth and development of bacteria causing of caries and the decrease of plaque score significantly happened in the using of toothpaste and mouthwash with betel leaves extract, showed that betel leaves with its composition can prevent the dental caries..$^{4,17}$

The change of saliva because of chewing betel habit and the using of mouthwash with betel leaves extract

Saliva consisted of organically component that is antimicrobial protein. Protein can prevent bacterial sticking metabolism in oral cavity, especially on the surface of the teeth. Lysozyme as one of saliva protein has antimicrobial characteristics and can activate bacterial autolysis ability especially to destroy bacterial wall cell, for example cariogenetic bacteria Streptococcus mutants. ${ }^{18}$

Peroxidase system, in saliva, derived from two enzymes, salivary peroxidase and myloperoxidase. Both enzymes can work actively with the existence of ion thiocynate $(\mathrm{S} C N)$ and hydrogen peroxide. The system of antimicrobial mechanism of salivary peroxidase is peroxidase enzyme as catalisator of hydrogen peroxide into hypothiocynate $(\mathrm{OSCN}-)$. Hypothiocynate is a component generally found at parotid glands, submandibular and other salivary glands. Biologically functions of these are as a potential antimicrobial and prevent proteins and its cell from the poisonous hydrogen peroxide..$^{18}$

In normal saliva and good health condition, hopefully others biology's function is also in the good condition. The function of protection againts cariogenic bacterial such as Streptococcus mutants and Lactobacillus can also be done by enzyme system in saliva, those are lysozyme, lactoperoxidase and myloperoxidase and total salivary peroxidase. Those enzymes need certain condition to do their job as antimicrobial agent. ${ }^{18}$

Peroxide system is important to consider as preventive initiation in the beginning of dental 
caries process, more hypothiocynate is formed, and then smaller number of acid plaque can be stick to the dental surface especially after a few minutes of sugar consumption. It's known that normal secretion speed is $0.3 \mathrm{~mL} /$ minutes without stimulant and $1.5-2 \mathrm{~mL} /$ minutes with stimulant. That's the reason that it is important to decide a certain number of amounts as a standard. If the number are the same with or smaller than $0.7 \mathrm{~mL} /$ minutes with stimulant then it is low. Someone with secretion speed under $0.7 \mathrm{~mL} /$ minutes with stimulant considered in high risk caries group. ${ }^{8}$

According to Fauziyah ${ }^{14}$, the using of betel leaves for mouthwash (with comparative composition of 32 grams betel leaves and 100 $\mathrm{mL}$ water) for 60 second can increase salivary peroxidase activity. Based on the counting of salivary peroxidase activity, approximately salivary peroxidase activity before gargling with boiled betel leaves is $16.30 \mathrm{IU} /$ liters. Then this approximate peroxidase activity is increased highly after gargling, $51.66 \mathrm{IU} /$ liters. The increase of approximate salivary perioxidase activity caused by the increased of saliva flow after gargling which caused the hypothiocyanate concentrate higher. The increase of saliva flow will also cause the increase of $\mathrm{pH}$, which will caused the increase of salivary peroxidase activity. Moreover, the use of mouthwash can also obstruct or kill bacteria in saliva which form the plaque.

The increase of saliva secretion could be happened because of mechanical stimulant such as chewing hard food or gum, chemically by taste stimulant, for example sour, sweet, salty, bitter and spicy. Dyah and Zahreni have done an experiment about saliva secretion to the smoker and betel chewer at advance age in Jember with 84 samples. ${ }^{19}$

Based on the data of Dyah and Zahreni ${ }^{19}$ research, who counted advance age saliva secretion score reported that the number of saliva secretion for smoker, betel chewer and control group approximately are $0.37371 \mathrm{~mL} /$ minutes, 0.63393 $\mathrm{mL} /$ minutes and $0.53857 \mathrm{~mL} /$ minutes. The lowest saliva secretion is on the smoker and the highest is on the betel chewer. This is happened because of the mechanical stimulant in chewing the quid ingredients. This stimulant will increase the stimulant of taste recipient, with the result that impulse flow through afferent nerve increased which followed by the increased stimulants on the center arrangement of saliva nerve increased and caused the increased of salivary secretion. However, it's not possible the substances contained in the betel chewing ingredients influences the saliva arrangement center chemically which can be caused the increased of saliva secretion.

The increased of secretion and saliva flow caused of betel leaves will increase the clean effect against food remains and acids made from carbohydrate glycolysis. The increased of saliva secretion will also increase the saliva buffer capacity, in order to neutralize to carbohydrate glycosis. Moreover, the increased of saliva secretion will increased the urea level in saliva. Urea consisted in saliva is a key factor in stabilizing plaque especially in breaking time (not eat). The reason is metabolic urea processed by oral microorganism through hydrolysis with urease enzyme as the mediator becoming ammoniac $\left(\mathrm{NH}_{3}\right)$ and $\mathrm{CO}_{2}$ is faster than carbohydrate glycolysis. The forming of $\mathrm{NH}_{3}$ is an alkali, it able to neutralize the acid made from carbohydrate glycolysis and will increase plaque $\mathrm{pH}$ which is decreased due to carbohydrate consumption. ${ }^{19}$

$\mathrm{pH}$ of plaque level is influenced by hydrolysis alkali effect of saliva urea and acid characteristics count from carbohydrate glycolysis. The sums of both will count the $\mathrm{pH}$ of plaque. In the breaking time, the produced alkali from metabolism of urea is worked, so that the $\mathrm{pH}$ of plaque is higher. However, after the consumption of carbohydrate the decreased of plaque $\mathrm{pH}$ happened as the result of carbohydrate glycosis.

The increased of a saliva secretion when chewing and mouth-washing with betel leaves followed by the increased of salivary peroxide system, the increase of clean effect by saliva, the increased of saliva buffer capacity and the increased of saliva urea level are the obstruction factors of the growth of plaque and oral cavity bacteria, which caused, in order to prevent teeth from the dental caries. ${ }^{20}$

\section{CONCLUSION}

Betel leaves consist of active ingredients function as anti-microbial agents and antiseptics in order to be one of the factors to obstruct the dental caries. Betel leaves can increase secretion 
and saliva function in order to be one of factors to obstruct dental caries.

\section{REFERENCES}

1. Darwis SN. Potensi sirih (Piper Beetle L) sebagai tanaman obat. Warta Tumbuhan Obat Indonesia 1992;1(1).

2. Prayogo BEW, Sutaryadi. Pemanfaatan sirih untuk pelayanan kesehatan primer. Warta Tumbuhan Obat Indonesia; 1992;1:1.

3. Kidd EAM, Bechal SJ. Dasar-dasar karies, penyakit, dan penanggulangannya. Jakarta: Penerbit Buku Kedokteran EGC; 1992.

4. Kumala A, Soedjono S. Pengaruh obat kumur rebusan daun sirih (Piper betle linn) terhadap plak dan gingivitis. J Ilmu dan Tek Kedokt Gigi FKG UPDM. 2006;3(1):176-80.

5. Heyne K. Tumbuhan berguna. Vol. II. Jakarta: Yayasan Wanajaya; 1982.

6. Perry LM. Medicinal plants of East and Southest Asia. London: The Mit Press; 1980.

7. Roberson TM, Lundeen TF. Cariology: the lession, etiology, prevention, and control. 2000. p. 65-7,91-6.

8. Axelsson, Karlstrad S. Diagnosis and risk prediction of dental caries. Vol. 2. Sweden: Quintessence Publishing Co., Inc.; 2000. p. 1 6,14-22,95-9,179-80,151-71.

9. Dalimartha S. Atlas tumbuhan obat Indonesia. Jil 4. Jakarta: Puspa Swara; 2006. p. 87-90.

10. Moeljanto RD, Mulyono. Khasiat dan manfaat daun sirih. Depok: Agromedia Pustaka; 2003.

11. Hendrayani SF. Pengaruh beberapa ekstrak daun sirih (Piper betle linn) terhadap pertumbuhan Candida albicans. Disertasi.
Bogor: Program Pacasarjana Institut Pertanian Bogor; 2005. p. 26-30.

12. Saka NT. Etnobotani sirih-pinang dalam kehidupan suku Ruteng di Kabupaten Manggarai. Disertasi. Bogor: Program Pacasarjana Institut Pertanian Bogor; 2001. p. 49-52.

13. Sukarminah E. Kajian sifat antimikroba ekstrak daun sirih (Piper betle linn) terhadap pertumbuhan mikroba perusak dan patogen makanan. Disertasi. Bogor: Program Pacasarjana Institut Pertanian Bogor; 1997.

14. Fauziyah EL. Analisis efek kumur-kumur air rebusan daun sirih selama 60 detik terhadap aktifitas peroksidase saliva. Skripsi. Jakarta: Departemen Penyakit Mulut FKG UI; 2006.

15. Anggriadi MZ. Efektifitas daya anti bakteri rebusan Piper betle linn terhadap pertumbuhan Streptococcus B secara in vitro. Skripsi. Jakarta: FKG USAKTI; 2005. p. 28.

16. Yunilawati R. Minyak atsiri daun sirih sebagai antibakteri Streptococcus mutans dalam pasta gigi. Bogor: FMIPA IPB; 2002.

17. Prahasanti C. Pengaruh pasta gigi yang mengandung ekstrak daun sirih terhadap pertumbuhan plak gigi. Maj Kedokt Gigi FKG UNAIR 2000;33:127-9.

18. Djamil MS. Mekanisme fluor menghambat kerja enzim air liur. J Kedokt Gigi UI 2000;7:1-6.

19. Dyah I, Zahreni H. Sekresi saliva pada lansia yang merokok dan menyirih di Kabupaten Jember. Maj Kedokt Gigi FKG UNAIR 2001;34:632-5.

20. Santoso R, Kanzil LB. Manfaat mengunyah keju terhadap pencegahan karies gigi. Jakarta: Maj Ilmu Kedokt Gigi FKG Usakti 1996;2:607-11. 